\title{
APOLIPOPROTEIN E PHENOTYPES AND SERUM LIPID LEVELS IN APPARENTLY HEALTHY MALE ADULTS IN TOKYO
}

\author{
Shigeru Tsuchiya, ${ }^{1}$ Yasuko Yamanouchi, ${ }^{2}$ Ryunosuke MryazaKI, ${ }^{3}$ \\ Mieko OnukI, ${ }^{2}$ Kimiko Yamakawa, ${ }^{2}$ Ikuko Kondo, ${ }^{2}$ \\ Minoru OHNUKI, ${ }^{1}$ and Hideo HaMaguCHI ${ }^{2}$ \\ ${ }^{1}$ Department of Nursing and Rehabilitation Medicine, Institute of \\ Community Medicine, and \\ ${ }^{2}$ Department of Human Genetics, Institute of Basic Medical Sciences, \\ University of Tsukuba, Sakura-mura, Ibaraki 305, Japan \\ ${ }^{3}$ Kudanzaka-Hospital, Kudanzaka-minami, Chiyoda-ku, \\ Tokyo 102, Japan
}

\begin{abstract}
Summary This study was performed to investigate whether the $\varepsilon 4$ allele of the apolipoprotein (apo) E predisposes Japanese male adults in large cities to hyperlipidemia. The apo E phenotypes and serum total lipid levels were determined using blood samples obtained after an overnight fast from 85 apparently healthy Japanese male civil servants in Tokyo. The frequency of hyperlipidemia was $50.0 \%$ in 20 subjects with the apo E4-positive phenotype and $25.8 \%$ in 62 subjects with the apo E3/3 phenotype. The difference is statistically significant $(\mathrm{p}<0.05)$. The mean $( \pm S D)$ serum triglyceride levels, which were calculated on the subjects with serum triglyceride lower than $250 \mathrm{mg} / \mathrm{dl}$, was $132.8 \pm 5.1 \mathrm{mg} / \mathrm{dl}$ in 18 subjects with the apo E4-positive phenotype and $108.4 \pm 43.0 \mathrm{mg} / \mathrm{dl}$ in 58 subjects with the apo E3/3 phenotype. The difference is also statistically significant $(\mathrm{p}<0.05)$. The data suggest that the $\varepsilon 4$ allele might predispose Japanese adults in large cities to hyperlipidemia.
\end{abstract}

\section{INTRODUCTION}

Apolipoprotein (apo) $\mathrm{E}$ is a normal protein constituent of human plasma very low density lipoproteins (VLDL), intermediate density lipoproteins (IDL), chylomicrons, chylomicron remnants, and a subfraction of the high density lipoproteins (HDL) (Shelburne and Quarfordt, 1974; Weisgraber and Mahley, 1978; Mahley and Innerarity, 1983). Apo E plays a central role in the metabolism of cholesterol and triglyceride: It serves as a mediator of the cellular uptake of specific plasma lipoproteins through an interaction with apo B,E receptor and apo E receptor, and 
is also involved in the conversion of VLDL to the low density lipoproteins (LDL) (Mahley and Innerarity, 1983; Ehnholm et al., 1984). In man, the locus for apo E is polymorphic (Utermann et al., 1977; Zannis et al., 1981, 1982). Three common alleles, designated $\varepsilon 2, \varepsilon 3$, and $\varepsilon 4$, code for three common apo $\mathrm{E}$ isoforms, apo E2, apo $\mathrm{E} 3$ and apo E4, respectively, and determine six apo $\mathrm{E}$ phenotypes (Zannis et al., 1982). The three common alleles have been demonstrated to exist in various populations (Utermann et al., 1982; Wardell et al., 1982; Ghiselli et al., 1982a; Cumming and Robertson, 1984; Sing and Davignon, 1985; Asakawa et al., 1985; Tsuchiya et al., 1985).

In Japanese, the $\varepsilon 3$ allele is the most common and the $\varepsilon 4$ allele is the second commonest, as in other populations studied thus far (Asakawa et al., 1985; Tsuchiya et al., 1985). In Caucasian populations, there is growing evidence that the $\approx 4$ allele might be involved in predisposing one to hyperlipidemia (Ghiselli et al., 1982a, 1982b; Utermann et al., 1984; Sing and Davignon, 1985). The purpose of this study is to investigate whether the $\varepsilon 4$ allele predisposes Japanese male adults in large cities to hyperlipidemia.

\section{MATERIALS AND METHODS}

Blood samples were obtained after an overnight fast from 85 apparently healthy Japanese male civil servants working in a government agency in Tokyo. They visited the health care center of Kudanzaka Hospital, Tokyo, for their annual health examinations. Their mean ( \pm SD) age was $47.1 \pm 7.1$ (range 35-64). The phenotypes of apo $\mathrm{E}$ was determined by two-dimensional gel electrophoresis as described previously (Tsuchiya et al., 1985). Serum total cholesterol and triglyceride were measured enzymatically (Allain et al., 1974; Sampson et al., 1975) on an automated analyzer (Hitachi Model 712, Hitachi Ltd., Tokyo). Statistical analysis of the frequency of hyperlipidemia was done by $\chi^{2}$-analysis. Statistical analysis of the serum lipid concentration was done by a one-way analysis of $t$ test.

\section{RESULTS}

In the 85 males examined, 62 males were the apo E3/3 phenotype, 18 males were the apo $\mathrm{E} 3 / 4$ phenotype, two males were the apo E4/4 phenotype, two males were the apo E2/3 phenotype, and one male was the apo E2/5 phenotype. All the subjects had normal thyroid, liver, and kidney function. Four apo E3/3 and one apo E3/4 phenotype subjects were found to have diabetes mellitus. Since serum total cholestrol and triglyceride concentrations were not substantially influenced by age in this study, serum lipid levels were not adjusted for age. Table 1 presents frequencies of hyperlipidemia (serum total cholesterol $>250 \mathrm{mg} / \mathrm{dl}$ and/or serum total triglyceride $>160 \mathrm{mg} / \mathrm{dl}$ ) in 62 subjects with the apo E3/3 phenotype and in 20 subjects with the apo E4-positive phenotype (apo E3/4 and apo E4/4). The 
Table 1. Frequencies of hyperlipidemia in subjects with the apo E3/3 phenotype and apo E4-positive phenotype.

\begin{tabular}{lcc} 
Apo E3/3 & $\begin{array}{c}\text { Apo E4-positive } \\
(\mathrm{E} 3 / 4 \& \mathrm{E} 4 / 4) \\
(\mathrm{n}=20)\end{array}$ \\
\hline Hypercholesterolemia $^{\mathrm{a}}$ without hypertriglyceridemia & $2(3.2 \%)$ & $2(10.0 \%)$ \\
Hypercholesterolemia and hypertriglyceridemia & $2(3.2 \%)$ & $2(10.0 \%)$ \\
Hypertriglyceridemia ${ }^{\mathrm{b}}{ }^{\circ}$ without hypercholesterolemia & $12(19.4 \%)$ & $6(30.0 \%)$ \\
Total & $16(25.8 \%)$ & $10(50.0 \%)^{*}$ \\
\hline
\end{tabular}

${ }^{a}$ Hypercholesterolemia: serum total cholesterol $>250 \mathrm{mg} / \mathrm{dl}$. ${ }^{\mathrm{b}}$ Hypertriglyceridemia: serum total triglyceride $>160 \mathrm{mg} / \mathrm{dl} . \quad * \chi_{1}{ }^{2}=4.09, \mathrm{p}<0.05$.

Table 2. Mean serum total cholesterol and triglyceride levels in subjects with the apo E3/3 phenotype and apo E4-positive phenotype.

\begin{tabular}{ccc} 
& Apo E3/3 & $\begin{array}{c}\text { Apo E4-positive } \\
(\mathrm{E} 3 / 4 \& \text { E4/4) }\end{array}$ \\
\hline Serum cholesterol & $201.0 \pm 30.1$ & $209.7 \pm 37.2$ \\
$(\mathrm{n}=62)$ & $(\mathrm{n}=20)$ \\
Serum triglyceride & $108.3 \pm 43.1$ & $132.8 \pm 51.1^{*}$ \\
$(\mathrm{n}=58)$ & $(\mathrm{n}=18)$
\end{tabular}

The values are mean concentrations $\pm S D(\mathrm{mg} / \mathrm{dl})$. Mean triglyceride concentrations were calculated on the subjects with serum triglyceride lower than $250 \mathrm{mg} / \mathrm{dl}$. $* t=1.836, \mathrm{p}<0.05$.

mean $( \pm \mathrm{SD}$ ) age was $47.1 \pm 7.5$ (range $36-63$ ) in the apo E3/3 phenotype group and 48.4 \pm 8.7 (range 35-64) in the apo E4-positive phenotype group. In the 62 subjects with the apo E3/3 phenotype, 16 subjects $(25.8 \%)$ had hypercholesterolemia or hypertriglyceridemia or both. In the case of 20 subjects with the apo E4-positive phenotype, however, 10 subjects $(50.0 \%)$ had hyperlipidemia. The difference is statistically significant $\left(\chi^{2}=4.09 ; \mathrm{p}<0.05\right)$.

The mean $( \pm S D)$ serum total cholesterol levels were $201.0 \pm 30.1 \mathrm{mg} / \mathrm{dl}$ (range 139-285) in the 62 apo E3/3 phenotype subjects and $209.7 \pm 37.1 \mathrm{mg} / \mathrm{dl}$ (range 138271 ) in the 20 apo E4-positive subjects (Table 2). The difference is not significant, probably because of a small sample size. The mean $( \pm S D)$ serum total triglyceride levels were $125.6 \pm 79.5$ (range 46-422) in the apo E3/3 phenotype group and $154.8 \pm$ 83.1 (range 66-354) in the apo E4-positive phenotype group. Since a few subjects with serum triglyceride greater than $250 \mathrm{mg} / \mathrm{dl}$ raised the mean triglyceride levels by about $20 \mathrm{mg} / \mathrm{dl}$ in both groups and since the values for triglyceride of these subjects were distributed apart from the values for triglyceride of the other subjects, we excluded these subjects from the analysis of mean triglyceride levels. The mean $( \pm \mathrm{SD})$ triglyceride levels, which were calculated on the subjects with serum triglyc- 
eride lower than $250 \mathrm{mg} / \mathrm{dl}$, were $108.4 \pm 43.0$ in the apo E3/3 phenotype group and $132.8 \pm 51.1$ in the apo E4-positive phenotype group (Table 2). The difference is statistically significant $(t=1.836 ; \mathrm{p}<0.05)$.

All the four diabetic males with the apo E3/3 phenotype were normolipidemic; the one diabetic male with the apo E3/4 phenotype was 42 years old and hypertriglyceridemic (serum total triglyceride $354 \mathrm{mg} / \mathrm{dl}$ ). Two subjects with the apo E2/3 phenotype were normolipidemic. The one subject with the apo E2/5 phenotype had a mild degree of hypertriglyceridemia, as described elsewhere (Tsuchiya et al., 1985).

\section{DISCUSSION}

Among the three common apo E alleles, only the $\varepsilon 3$ allele has yet to be associated with any of the lipid disorders. It is well established that the $\varepsilon 2$ allele, especially the homozygote for $\varepsilon 2$, is associated with type III hyperlipidemia (Breslow et al., 1982; Ghiselli et al., 1982a; Havel, 1982). As to the $\varepsilon 4$ allele, Ghiselli et al. (1982a, 1982b) reported an association with type $V$ hyperlipoproteinemia and Utermann et al. (1984) observed an association with hypercholesterolemia and mixed hyperlipidemia. Furthermore, it is suggested that the $\varepsilon 4$ allele raises plasma total cholesterol in normolipidemic individuals (Sing and Davignon, 1985). Since the $\approx 4$ allele is considered to act as a polymeric gene in predisposing one to hyperlipidemia, if the $\varepsilon 4$ allele is associated with hyperlipidemia, and since a diet of a population has a considerable effect on serum lipid levels of the population, the results obtained in Caucasian populations may not be applied to Japanese. Therefore, we have examined serum lipid levels of apparently healthy Japanese civil servants working in Tokyo, in connection with the $\varepsilon 4$ allele. In the present study, significantly higher frequency of hyperlipidemia and mean serum triglyceride level were observed in the subjects with the apo E4-positive phenotype, as compared to the subject with the apo E3/3 phenotype. The results suggest that the $\varepsilon 4$ allele might predispose Japanese adults in large cities to hyperlipidemia, too.

Our results are consistent with the concept that the $\varepsilon 4$ allele predisposes one to the development of hyperlipidemia. At present, however, it is difficult to explain the mechanism by which the $\varepsilon 4$ allele pedisposes one to hyperlipidemia. Apo E4 differs from apo E3 by an amino acid substitution at residue 112 on the 299 amino acid chain of the apo E molecule: Apo E3 has cysteine at site 112, while apo E4 has arginine (Rall et al., 1982a, 1982b; Weisgraber et al., 1982). However, no difference has been observed in the binding activity to apo B,E recepter between apo E3 and apo E4 (Weisgraber et al., 1982). As to the binding activity to apo $\mathrm{E}$ receptor and the function for the conversion of VLDL to LDL, it is not determined whether there are some differences between apo E3 and apo E4. In addition, the type of hyperlipidemia associated with the $\varepsilon 4$ allele is not established yet. Further biochemical, genetic, clinical, and epidemiological investigations are necessary to establish and characterize the association of the $\varepsilon 4$ allele and hyperlipoproteinemia. 
Acknowledgments This investigation was supported by a Scientific Research Grant from the Ministry of Education, Science and Culture, and a Research Grant for Intractable Diseases from the Ministry of Health and Welfare, Japan.

\section{REFERENCES}

Allain, C.C., Poon, L.S., Chan, F.C.S., Richmond, W., and Fu, C.P. 1974. Enzymatic determination of total serum cholesterol. Clin. Chem. 20: 470-475.

Asakawa, J., Takahashi, N., Rosenblum, B.B., and Neel, J.V. 1985. Two-dimensional gel studies of genetic variation in the plasma proteins of Amerindians and Japanese. Hum. Genet. 70: 222-230.

Breslow, J.L., Zannis, V.I., SanGiacomo, T.R., Third, J.L.H.C., Tracy, T., and Glueck, C.J. 1982. Studies of familial type III hyperlipoproteinemia using as a genetic marker the apo E phenotype E2/2. J. Lipid Res. 23: 1224-1235.

Cumming, A.M. and Robertson, F.W. 1984. Polymorphism of the apoprotein-E locus in relation to risk of coronary disease. Clin. Genet. 25: 310-313.

Ehnholm, C., Mahley, R.W., Chappell, D.A., Weisgraber, K.H., Ludwig, E., and Witztum, J.L. 1984. Role of apolipoprotein $E$ in the lipolytic conversion of $\beta$-very low density lipoproteins to low density lipoproteins in type III hyperlipoproteinemia. Proc. Natl. Acad. Sci. USA 81: $5566-5570$.

Ghiselli, G., Gregg, R.E., Zech, L.A., Schaefer, E.J., and Brewer, H.B., Jr. 1982a. Phenotype study of apolipoprotein $\mathrm{E}$ isoform in hyperlipoproteinemic patients. Lancet ii: 405-407.

Ghiselli, G., Schaefer, E.J., Zech, L.A., Gregg, R.E., and Brewer, H.B., Jr. 1982b. Increased prevalence of apolipoprotein $\mathrm{E} 4$ in type $\mathrm{V}$ hyperlipoproteinemia. J. Clin. Invest. 70: 474 477.

Havel, R.J. 1982. Familial dysbetalipoproteinemia. New aspects of pathogenesis and diagnosis. Med. Clin. North. Am. 66: 441-454.

Mahley, R.W. and Innerarity, T.L. 1983. Lipoprotein receptors and cholesterol homeostasis. Biochim. Biophys. Acta 737: 197-222.

Rall, S.C., Jr., Weisgraber, K.H., Innerarity, T.L., and Mahley, R.W. 1982a. Structural basis for receptor binding heterogeneity of apolipoprotein $\mathrm{E}$ from type III hyperlipoproteinemic subjects. Proc. Natl. Acad. Sci. USA 79: 4696-4700.

Rall, S.C., Jr., Weisgraber, K.H., and Mahley, R.W. 1982b. Human apolipoprotein E. Complete amino acid sequence. J. Biol. Chem. 257: 4171-4175.

Sampson, E.J., Demers, L.M., and Krieg, A.F. 1975. Faster enzymatic procedure for serum triglycerides. Clin. Chem. 21: 1983-1985.

Shelburne, F.A. and Quarford, S.H. 1975. A new apolipoprotein of human plasma very low density lipoproteins. J. Biol. Chem. 249: 1428-1433.

Sing, C.F. and Davignon, J. 1985. Role of the apolipoprotein E polymorphism in determining normal plasma lipid and lipoprotein variation. Am. J. Hum. Genet. 37: 268-285.

Tsuchiya, S., Yamanouchi, Y., Onuki, M., Yamakawa, K., Miyazaki, T., Taya, T., Kondo, I., Ohnuki, M., and Hamaguchi, H. 1985. Frequencies of apolipoprotein E5 and E7 in Japanese. Jpn. J. Human Genet. 30: 271-278.

Utermann, G., Hees, M., and Steinmetz, A. 1977. Polymorphism of apolipoprotein E and occurrence of dysbetalipoproteinemia in man. Nature 269: 604-607.

Utermann, G., Steinmetz, A., and Weber, W. 1982. Genetic control of human apolipoprotein E polimorphism: Comparison of one- and two-dimensional techniques of isoprotein analysis. Hum. Genet. 60: 344-351.

Utermann, G., Kindermann, I., Kaffarnik, H., and Steinmetz, A. 1984. Apolipoprotein E phenotypes and hyperlipidemia. Hum. Genet. 65: 232-236.

Wardell, M.R., Suckling, P.A., and Janus, E.D. 1982. Genetic variation in human apolipoprotein 
E. J. Lipid. Res. 23: 1174-1182.

Weisgraber, K.H., Innerarity, T.L., and Mahley, R.W. 1982. Abnormal lipoprotein receptorbinding activity of the human apoprotein $\mathrm{E}$ due to cysteine-arginine interchange at a single site. J. Biol. Chem. 257: 2518-2521.

Weisgraber, K.H. and Mahley, R.W. 1978. Apoprotein (E-A-II) complex of human plasma lipoproteins. I. Characterization of this mixed disulfide and its identification in a high density lipoprotein subfraction. J. Biol. Chem. 253: 6281-6288.

Zannis, V.I., Just, P.W., and Breslow, J.L. 1981. Human apolipoprotein E isoprotein subclasses are genetically determined. Am. J. Hum. Genet. 33: 11-24.

Zannis, V.L., Breslow, J.L., and Utermann, G. 1982. Proposed nomenclature of apo E isoproteins, apo E genotypes and phenotypes. J. Lipid. Res. 23: 911-914. 